\title{
2章 制作技術
}

\section{2-1 撮影技術：デイジタル時代の变遷と不变}

\section{畠野栄一郎}

キーワード：デイジタルシネマカメラ，超音波距離測定，アナモフィックレンズ，新たな職種

\section{1.まえがき}

フィルムは記録から芸術的表現へと発展した。そして撮 影に関わる機材の進化は新たな創造を湧きたてた。

24 駒で撮影できるHDディジタルカメラが登場してから 早 18年. 解像度がHD (High Definition Video) で始まった

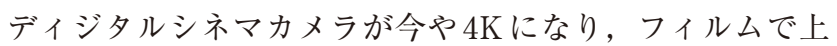
映していた映画館はプロジェクタへと様変わりした。撮影 に関わる機材の変化は目まぐるしく，新たな技術と製品が 現れたかと思えば消えていく，そんな時勢ではあるが，だ からこそ止まって覧古考新するのも良いように思える。

\section{2.ディジタルシネマカメラ}

\section{1 初めのEシネマ}

アナログ全盛期の頃，ビデオカメラでフィルムルックな 表現への挑戦は幾度となく繰り返されてきた.

1983年，テレビ放送がNTSC 全盛期の頃，池上通信機か らフィルムカメラを考慮したテレビカメラが登場した．機 種名を「EC-35」と言い (図1)，2/3インチのダイオードガ ンプランビコンを 3 本使用した撮像管カメラは, 形状や操 作性にダイナミックレンジなど，さまざま点において当時 のフィルムカメラを反映すべく設計されていた.

$\lceil$ EC-35」のECとは「Electronic Cinematography Camera」 の略でEシネマとも言われていた.

まさに映画がフィルムからディジタルに変わる，そんな 時代を予見させられるカメラであった。

\section{2 移り行くDシネマ}

2000 年にBSでディジタルハイビジョン放送が始まった 頃，ソニーが「HDW-F900 (CineAlta)」の発売を皮切りに パナソニックから「AJ-HDC27F (VARICAM)」が相次いで 登場した。その形状はテレビ放送の取材などで使用される ENG (Electronic News Gathering) と同型で，撮像素子は

†協同組合日本映画撮影監督協会/一般社団法人日本映画テレビ技術協会 "Production Technology; Capture Technology: Transition and Immutability of Digital Age" by Eiichiro Hatano (Japanese Society of Cinematographers (J.S.C.), Tokyo/Motion Picture and Television Engineering Society of Japan, Inc., Tokyo)

$684(42)$

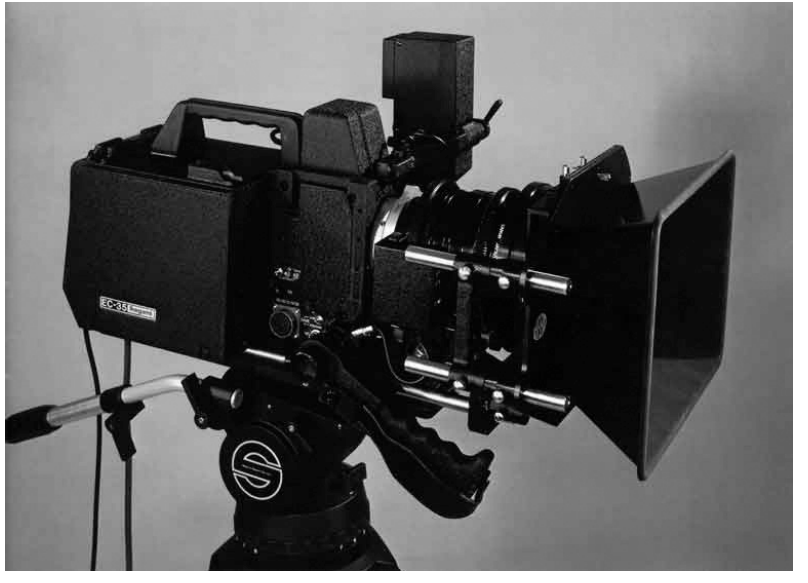

図 11983 年に登場した『EC-35』(提供：池上通信機)

色分解プリズムに配列された 3 板式 $2 / 3$ インチ $16: 9$ CCD (Charged-Coupled Devices) センサを使用していた。映画 用レンズはPL (Positive Lock) マウントが主流であったた め，新たにディジタルシネマカメラ用 $2 / 3$ インチレンズが 各社から発売された。

2006 年から 2008 年頃に掛けてソニーのCineAlta シリー ズから登場した「F-23」や「F-35」は従来の形を一新し映画 撮影を意識した形状となり，フィルムカメラで使用されて いるアクセサリーなどの互換性や運用性も向上した。

$\lceil F-23 」 の$ 撮像素子は放送用 ENG カメラと同様の 3 板式 2/3 インチ $16: 9$ CCD センサで，レンズマウントも放送用 としては標準的な B4 マウントになる.

$\lceil\mathrm{F}-35 」$ の撮像素子は，映画用フィルムのスーパー $35 \mathrm{~mm}$ $(24.92 \mathrm{~mm} \times 18.67 \mathrm{~mm})$ に相当する $23.62 \mathrm{~mm} \times 13.28 \mathrm{~mm}$ の 単板型 CCD センサで，レンズマウントはPLマウントを採 用することで映画撮影用レンズを使用することが可能と なった。

記録方式は共にHD フォーマットなのでDCI（Digital Cinema Initiatives）の仕様を満たしていないが，当時の ディジタルシネマカメラは上映用フィルムへのプリントが 主な目的としていたので経済的にも現状に沿った技術で

映像情報メディア学会誌 Vol. 72, No. 5, pp. 684〜688（2018） 
あった。

海外でも同時期からディジタルシネマカメラの開発が活 発となり, HD解像度からオーバ $2 \mathrm{~K}$ や高速度カメラなどさ まざまなモデルが登場した。その多くは形状や操作性にス ペックなど, 次世代の映画撮影用ディジタルカメラを目指 しており, 撮像素子も国内では HD 解像度が全盛期の頃, 海外ではオーバ $2 \mathrm{~K}$ の開発が活発となっていた.

2003 年に発売されたThomson Grassvalley（現： Grassvalley)の「Viper FilmStream Camera」(通称：Viper) は，形状やレンズマウントも一般的な放送用カメラであっ たが，3板式 $2 / 3$ インチ 920 万画素HD-DPM + CCD センサ (DPM: Dynamic Pixel Management) の有効画素数は $1920 \times 4320$ pixels と特殊なセンサで, メカニカルシャッタ による読み出し方法など外見に似つかわしくないスペック であった。

同年に発表されたDALSA（現：Teledyne DALSA Corporation)の「Origin」は撮像素子が $34 \mathrm{~mm} \times 17 \mathrm{~mm}$ の 単板型ベイヤーパターンで, 総画素数は $4046 \times 2048$ pixels とすでに $4 \mathrm{~K}$ 解像度のディジタルシネマカメラが登場して いた。

2004年にPanavisionがソニーと共同開発した「GENESIS」 はレンズやアクセサリーなど使用はPanavisionの専用設計 だが，撮像素子は「F-35」と同じ $23.62 \mathrm{~mm} \times 13.28 \mathrm{~mm}$ の単 板型CCDを使用している。

2005年，ARRIがディジタルシネマカメラに参入した「D$20 」$ の撮像素子は，映画撮影用ネガフィルムのスーパー 35 $\mathrm{mm}$ サイズに相当する $24.9 \mathrm{~mm} \times 18.15 \mathrm{~mm}$ の単板型べイ ヤーパターンで有効画素数は $2880 \times 2160$ pixelsになる.

そして2007年にRED (Red Digital Cinema Camera Company) がDALSA以来の $4 \mathrm{~K}$ ディジタルシネマカメラとし て「RED ONE」を発売した. 撮像素子は $24.4 \mathrm{~mm} \times 13.7 \mathrm{~mm}$ の単板型ベイヤーパターンで, 総画素数は $4900 \mathrm{~mm} \times 2580$ $\mathrm{mm}$ のスーパー35サイズになる.

その後DALSA は 2008 年に撤退し, RED 以外で $4 \mathrm{~K}$ 解像 度のディジタルシネマカメラが登場するのは 2012 年頃から になる。

\section{3 光学ファインダから電子ファインダへ}

映画用ディジタルカメラの開発が始まった当初, 多くが フィルムカメラと同様の回転ミラーシャッタによる光学 ファインダ (OVF) のデイジタルシネマカメラを模索してい た. 撮影者にとってとは画作りする上でも重要なファイン ダは慣れ親しんだということもあり光学ファインダを切望 する声も多かったが，その構造故から現在回転ミラー シャッタによる光学ファインダのデイジタルシネマカメラ はARRIFLEXの「ALEXA SXT Studio」のみとなった(図2). 電子ファインダ $(\mathrm{EVF})$ は今やカラーが当たり前だが，当 初はモノクロであったため早期のカラー化が切望された. これは撮影時に色が判別できないということもあるが，小

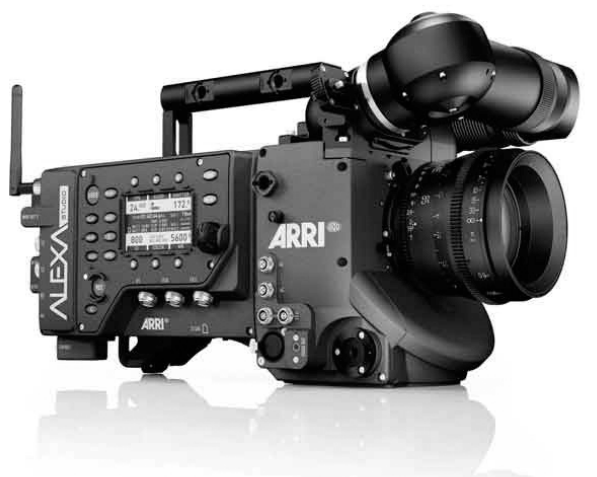

図2 回転ミラーシャッタによる光学ファインダを搭載した電子ファ インダにも交換可能な『ALEXA SXT Studio』 (提供 : ナックイメージテクノロジー)

さなモニタを咞くというストレスもあった。 その後液晶化 により色彩の判別は付くようになったが，新たな問題とし てフォーカスの認識がしづらくなった。モノクロが必ずし も判別しやすいというわけではなかったが，それにもまし てということになる. また, 液晶の電子ファインダはカメ ラを左右に動かすと遅延が生じる，遅延と言っても動き始 めのズレがしだいに追いつくと言った何とも気持ちの悪い 現象である。近年はかなり改善されたが, それでも程度に よっては演出的タイミングの齟齠や，延いてはストレスに もなる。

現在は有機 ELによる電子ファインダも出始め, 色域, フォーカス，即応性などにも期待されている.

だがこれは解像度が $2 \mathrm{~K} ま て ゙ の こ と て ゙ ， 4 \mathrm{~K}$ 解像度となる と HD解像度の電子ファインダではフォーカスの判断が極 めて難しくなる.

\section{4 ハイレゾリューションの焦点距離計測}

フィルムでの撮影では劇映画に限らず被写体に対して適 切な距離をメジャーで計測してきた。そして知識と経験に よる目測でも的確に計測する，言うなれば職人的技を有す る仕事である。だがHDカメラで映画を撮影する頃より，そ れまでの知識や経験だけでは適切に焦点距離を求めること が難しく，より精度の高い計測が必要となってきた４K で の撮影でもメジャーによる計測と長年の感覚で距離を測り フォーカスを送るという手法は行われているが，必ずしも 従来の手法で的確に計測ができるわけではなく，モニタや フォーカスアシストの機能なども駆使しなければ，的確な 焦点距離を計測することが困難となってきた．撮影に使用 される機材に超音波で距離を測定する装置があり（図3)，海 外ではこの装置を使用することで対策を講ずる傾向もある。

2.5 ディジタル時代のアナモフィックレンズ

HDの放送が始まった頃, アスペクト比がビスタビジョ ンと変わらないことからシネマスコープが話題に出るよう 


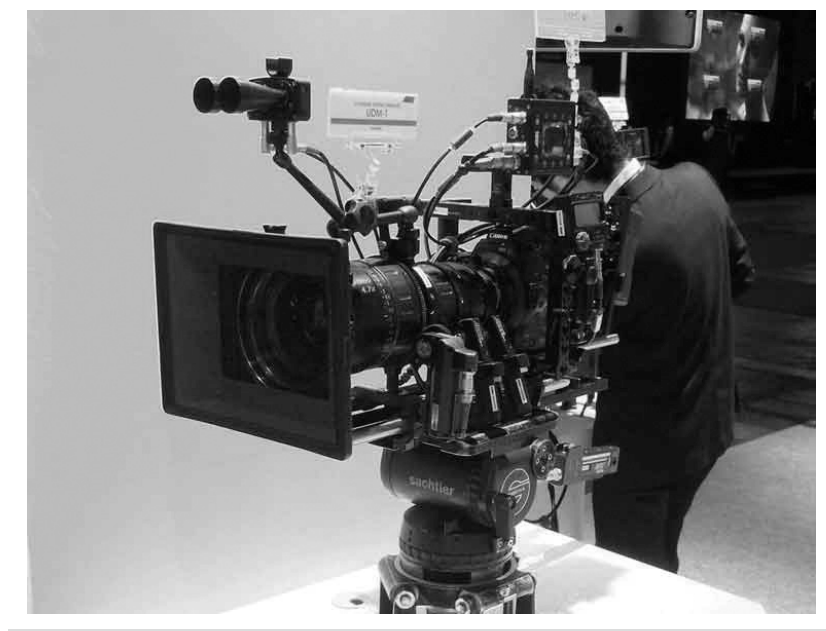

図3レンズ上部に装備した超音波距離計測装置 （提供：ナックイメージテクノロジー）

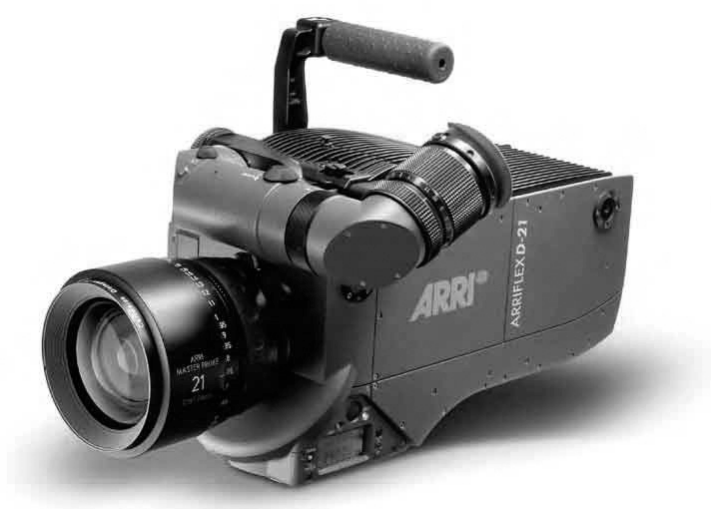

図4 Mscopeのモードを実装した『ARRIFLEX D-21』 （提供：ナックイメージテクノロジー）

になった。

ビスタビジョンとはアスペクト比が日本でも採用してい るアメリカン・ビスタの 1.85:1で, HDTVの 1.78:1 (16:9) とほほ同じになる. 対してシネマスコープのアスペクト比 は2.39: 1 と横に長い。この横長の画面を撮影するには上下 をトリミングするかアナモフィックレンズを使用する.

アナモフィックレンズとは画面の横方向を圧縮するレン ズで, 特殊な光学系の持ち味はこのレンズならではの表現 を酻し出す。

アナモフィックレンズで圧縮するアスペクト比は通常 $4: 3$ だが，キヤノンは 2004 年に $2.35: 1$ を 16:9のアスペクト比 に変換するアナモフィックコンバーター (ACV-235) を発売 した.このコンバーターはレンズとカメラの間に取り付け るリアコンバーターで，2/3 インチの HDカメラと HD用レ ンズで画素を損なわず横に広い映像を撮ることができる.

2008年にはARRIFLEXが「D-21」でアナモフィックレン ズを HD 撮影に使用できる「Mscope」を発表した (図4).

「Mscope」とは，4:3のアスペクト比を損失なく $16: 9$ の $\mathrm{HD}$ 解像度に変換するシステムになる。

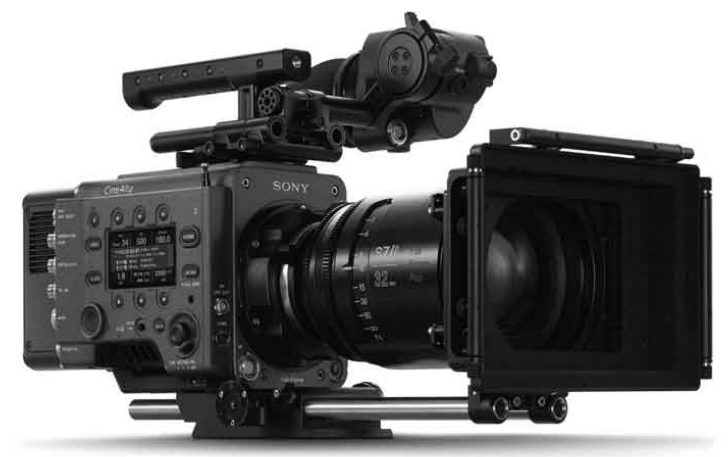

図 5 4:3のアナモフィックレンズに対応するソニー『VENICE』 （提供 : ソニービジネスソリューション）

その方法は, $4: 3$ のアナモフィックレンズで圧縮した映 像を同期した $16: 9$ のD 解像度に奇数と偶数のラインに分 割して，ポストプロダクションで再合成することで，アナ モフィックレンズで撮影した $4: 3$ の映像に戻す方法になる.

ディジタルシネマの撮影やワークフローは HD が標準的 だった当時シネマスコープの作品で，スペックを追求した 技術はその特異な方法が故に普及するには至らず，垂直解 像度が低下しても経済的にはトリミングの方法が採用され やすかった。

日進月歩のディジタル技術は，アナモフィックレンズの撮 影やトリミングによるアスペクト比の選択にも幅が出るま でになった. また, 光学系ファインダでアナモフィックレ ンズの圧縮されたイメージを認識するには経験を必要とし ていたが，電子ファインダの技術によりフレームの認識が 容易になり，解像度を維持した撮影もし易くなった (図5).

\section{3. ディジタル時代のイノベーション}

\section{1 記録メディアの変化}

国内の HD ディジタルカメラによる映画撮影で機材の管 理や運用などの技術支援は，通常VE (Video Engineer) が 担当していた．知識として上映用フィルムや映画の撮影技 術なども必要なのだが, 不足する知識や経験は撮影パート や現像所などがそれを補い，またはその知識を有する VE が補うなど，相互補完によって撮影が行われていた。

だが国内外を問わず多くは映画の撮影パートのみで行っ ており，準備の段階で操作などを最低限にすることでビデ オカメラに不慣れでも撮影を容易にすることができた。こ れはワンマンオペレーションで撮影ができるカメラであっ たからだが，それが故に一切を撮影者に委ねることで撮影 助手のアシストが阻害されることとなった。後に映画での 撮影と同様, 撮影助手のアシストによる分業が可能となり, それに伴う操作の簡素化も求められるようになった。

HD ビデオテープは当初 8 ビットで高圧縮だったが国内で は受け入れられていた。記録フォーマットは「シネガンマ」 
または「ハイパーガンマ」と称するITU-R709をベースに映 画撮影用ネガフィルムのラチチュードに近づけた，いわゆ るシネライクなビデオガンマが主流であった。 だが, 海外 では必ずしも受け入れられる状況ではなく，ストレージメ ディアによる 10 ビット非圧縮のデー夕記録が主流で, 「Viper」はHDフォーマットであったがRGB 4:4:4/10ビッ トの Logデータをストレージメディアに記録していた。

\section{2 ディジタルネガの管理}

ディジタルシネマカメラでネガフィルムのように撮影で きたのは「Viper」のLogデータに「RED ONE」のRawデー 夕.そして Log と Rawの両方を記録できたのが「D-20/21」 と限られていた。だが，HDビデオテープが10ビット低圧 縮記録になると新たなディジタルネガとなる Logが登場 し，HDビデオテープでもネガフィルムのように撮影する ことができるようになった。

2010 年頃, 上映がフィルムからディジタルシネマプロ ジェクタに変わると記録メディアもビデオテープからスト レージやメモリーカードへと変わり, Logデータや Raw データはオーバ $2 \mathrm{~K}$ で記録するようになった. だが，管理 や運用などの取り扱いはビデオテープと違い, 新たな知識 やルールが必要となった.

HD ビデオテープは長年の信頼や取り扱いの容易さから 記録されたオリジナルテープでポストプロダクションの作 業が行われていた。 だが，ストレージやメモリーカードは その信頼度からオリジナルデータでポストプロダクション の作業は行わず, 撮影済み記録データを保存用と作業用に 複製し作業用データでポストプロダクションの作業を行 い，撮影で使用した記録メディアは複製が問題なく完了し たことを確認できしだい消去している.

この複製を業界内ではクローンと呼称し国内外を問わずこ の作業は慣例となっていて, 国内では日本フィルムラボ協 会からも記録デー夕の取り扱いについて方針が出される.

クローンの作成に使用するメディアは国内外で違いがあ り，海外ではLTO (Linear Tape Open)なども使われてい るが，国内ではHDDやSSD な゙のストレージメディアが 一般的である。作業はPCによる専用ソフトで行うのが一 般的だが，海外では専用のユニットを使用している（図6).

3.3 色のコミュニケーション

ディジタルシネマカメラは色域やダイナミックレンジが 広がることでLogデータや Rawデータというデイジタルネ ガで撮影をするようになったが, それに伴いネガフィルム のような現像処理が必要となり, ディジタルネガの現像処 理や色調の調整をポストプロダクションでカラーグレー ディングという作業により行うのだが, カラーグレーディ ングの作業には膨大な時間を要し経済的にも効率が悪い. そこで作業の軽減や RGBの基本的な色補正情報を交換する コミュニケーションの必要性から ASC (American Society of Cinematographers) はASC-CDL (CDL: Color Decision

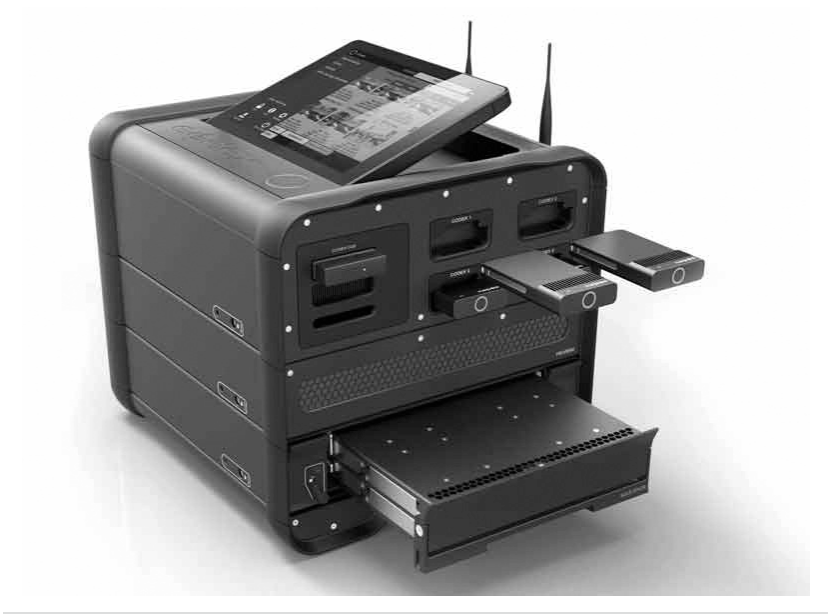

図6 データマネジメントユニットのCodex社製『Vault』 (提供 : ナックイメージテクノロジー)

List）という仕様を作成し推奨している. ASC-CDLはカ ラーマネジメントを目的としないシンプルな仕様になって いる。だがシンプルが故に色域や色温度の設定に色空間が Rec.709であるなど，運用性においても課題が残る.

カラーコミュニケーションとしてのASC-CDLに対して, AMPAS (Academy of Motion Picture Arts and Sciences) の ACES (Academy Color Exchange Specification) は撮影 から上映まで映像制作全体のカラーパイプラインとした規 格になる。

この規格により多種の入力デバイスと多種の出力デバイ スの不一致を統一した管理, 運用が可能となった。例えば, 合成用 CGの制作で撮影監督の立ち合いがなくても意図を 汲み取り反映することが可能となり, 出力デバイスの色空 間がITU-R709 と DCI-P3の違いによるカラーグレーディン グの作業も不要になる. また，ACES規格の定義された色 空間には従来の撮影用ネガフィルムや上映用ポジフィルム の色情報をマッピングすることができるので，フィルム ルックなイメージに仕上げることができる．また，マッピ ングの方法を変えることでテレシネルックにすることも可 能となるなど, 従来では不可能なトーンの表現も可能と なった。

\section{4 新たな職種}

ディジタルシネマカメラで撮影が始まった当初は, カ ラーグレーディングの作業負担からカラーリストとのグ レーディングに関する情報のコミュニケーションが必要と なり，そのため撮影監督 (DP:Director of photography) は デイリーグレーディングをカット毎に行っていたが必ずし も効率的ではなかった。 また，デー夕に関する取扱いなど 新たな技術的な問題を解決するには専門知識を有する技術 者の必要性が出てきた。

•DIT (Digital Imaging Technicians : ディー・アイ・ ティーまたはディット) は, 撮影からポストプロダク ションまでの全行程で統括した技術責任者で，撮影機 


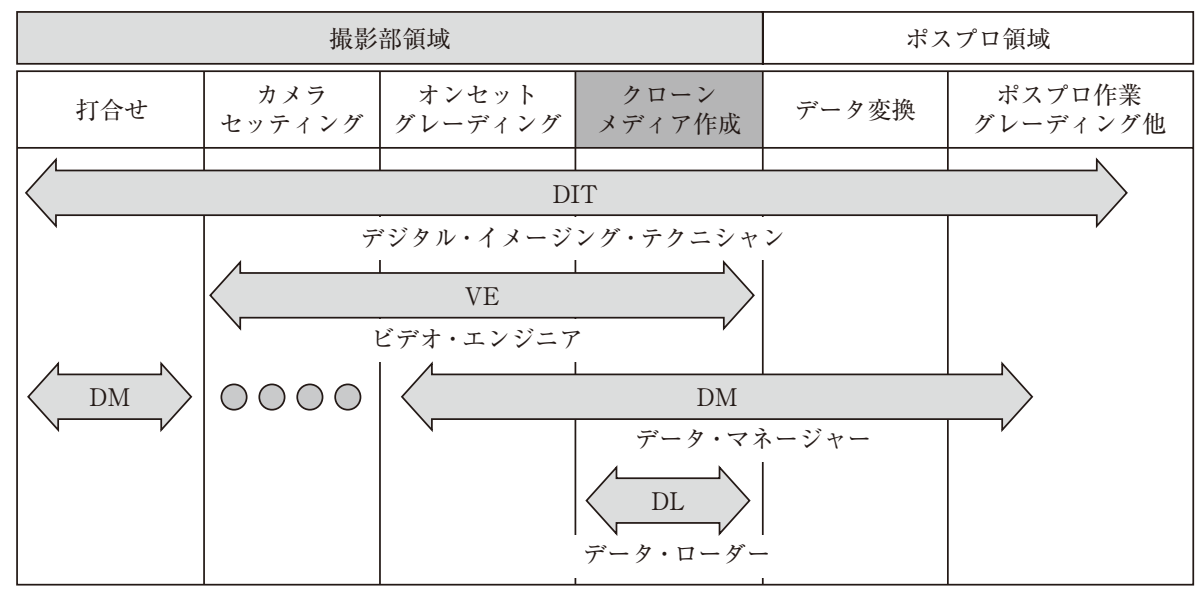

図7収録メディアと保存メディア（出典：文献1)）

材に関する技術的支援やデー夕の管理，そして中核と なるのがオンセットデイリーでカラーパイプラインで のオンセットグレーディングや技術的ワークフローの 管理運用となる。

・DM (Data Manager) は, データの管理やオンセット デイリーの作業も行う.

・DL (Data Loader) は, データの管理のみとなる.

これら新たな職種となる DIT P DM/DLは，映画以外に もコマーシャル $(\mathrm{CM})$ やプロモーションビデオ $(\mathrm{PV})$, そ してテレビやネットのドラマ制作でも活動している.

国内では経済的な観点からも最重要視するのがクローン の作成で, DITのみの場合も珍しくなく，またVEがその 役割を果たすこともある(図7)。

\section{4．照明機材の多様性}

タングステンの照明機材は撮影現場でお目に掛るのも珍 しくなり，今やHMI (Hydrargyrum Medium-arc Iodide) や蛍光管に加えて LEDの照明機材が主流となった。撮影用 照明の蛍光管は大きさや色温度などが多種多様で狭い場所 でも仕达む事ができ，影を抑えられ柔らかく拡散した光は ベースライトとしても重宝されたＬEDは放射熱が少なく 色温度を変化させられるモデルが多く, 蛍光管と同様フ ラットなタイプの他にフレネルレンズを使用したフォーカ ス調整の可能なモデルもある.

蛍光管とLED はその用途が似ており，光の強さや広がり の性質などの違いが新たな選択の幅となった。だが，タン グステンとは違う新たな照明機材は色偏差がメーカや経年 変化にも大きく影響され, 蛍光管や LEDの照明機材には色 温度や色偏差の調整機能が装備されているモデルもある.
タングステンでは色温度のコンバージョンフィルタで対応 できたが，HMIなど調整機能が装備されていないモデルに は色温度に加え色偏差のコンバージョンフィルタによる, タングステンにない調整が必要となった。

\section{5. むすび}

ディジタルシネマカメラが登場して以来, その形や使用 には紆余曲折があったが，フィルムで撮影していた頃の仕 様に近づくことでよりシンプルに，そして踏襲されてきた 技術を生かせるようになる，だが電子化故の便利さは，力 メラ周りが機材やケーブルで複雑な造形となり，撮影現場 では多様化する作業に多彩なデバイスをマッチングするた めのパイプラインは絡まった糸を解すようなものだ。ディ ジタルとは便利なようで不便となり，不便と思われていた アナログはとてもシンプルに見える。この先手に余るよう な状況となれば次は「AI」, なんてことも満更ではないかも しれない.

(2018年5月 31 日受付)

\section{〔文 献〕}

1）橋本伸夫：“CMファイルベース時代の新職種「データ・マネージャ」 と「データ・ローダー」”，映画テレビ技術誌，736，pp.26-27（Dec． 2013)

2) Using ASC CDL in a Digital Cinema workflow

3) ARRIFLEX D-21/D-21 HD

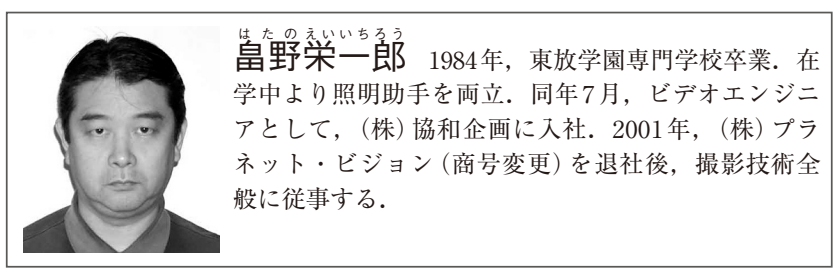

